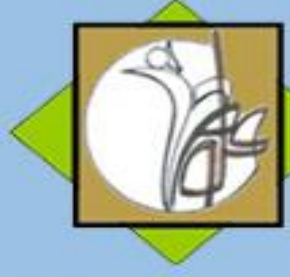

\title{
The Role of Negative News on the Attitude of Fans towards the Players and Persepolis Football Team
}

\author{
Sardar Mohammadi ${ }^{1}$, Mojtaba Ghasemi Siani ${ }^{2}$
}

1. Sardar Mohammadi, (Ph.D) Kurdistan University, Sanandij, Iran

2. Mojtaba Ghasemi Siani, (Ph.D Student) Kurdistan University, Sanandij, Iran

\section{ARTICLE INFO \\ Received February 2018 \\ Accepted August 2018}

\section{KEYWORDS:}

Negative information

Incompetence

Persepolis team

Immoral fans identity

CITE:

Mohammadi, Ghasemi Siani, The

Role of Negative News on the

Attitude of Fans towards the

Players and Persepolis Football

Team, Research in sport

management \& motor behavior,

2020: $9(18) 178-196$

\section{ABSTRACT}

The purpose of study was to investigate role of negative news about the attitude of fans towards the players and Persepolis football team. The population of study was all students of fans of Persepolis team in Kurdistan University. A sample of 200 people was selected and simple random sampling method was used for data collection. The research method was semi experimental and factorial design was $2 * 2 * 2$. Questionnaire was used to measure identity and attitude towards Persepolis team and Descriptive statistics and inferential (independent t-test, one way covariance analysis) were used to analyze the data. In the study, four types of negative information (immoral of game related, immoral of non-game related, Incompetent of game related, Incompetent of non-game related) on the attitude of fans towards the players and Persepolis team were investigated. The research findings showed that immoral negative information more than incompetence negative information results in negative attitudes towards fans and the Persepolis team. Also, the negative attitude to the Persepolis team and players in high and low identity fans is different in the negative news of the incompetence related and unrelated to sport, but is not the same in the negative immoral news of related and unrelated negative news. The Persepolis club can prevent the development of immoral and incompetence issues by controlling and monitoring the well-known players in the team. By preventing the publication of false and negative news from other news sources, it prevents fans from developing a negative attitude toward the team. 


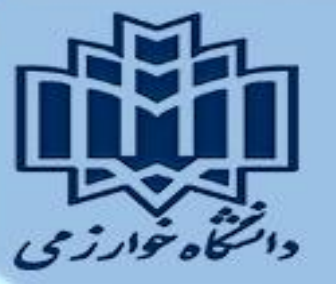

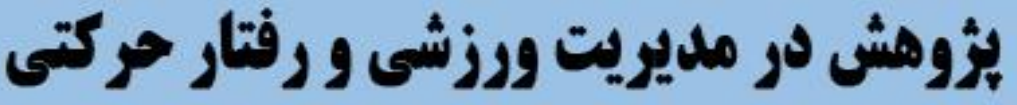

\section{نقش اطلاعات منفى بر نكَ ش هواداران نسبت به بازيكنان و تيم فوتبال بر سبوليس}

$$
\begin{aligned}
& \text { سردار محمدى'، مجتبى قاسمى سيانى } \\
& \text { 1. دانشجوى دكترى مديريت ورزشى، دانشگاه كردستان، سنتدج، ايران }
\end{aligned}
$$

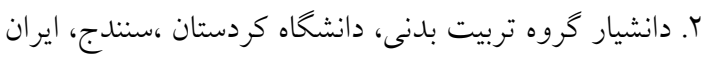

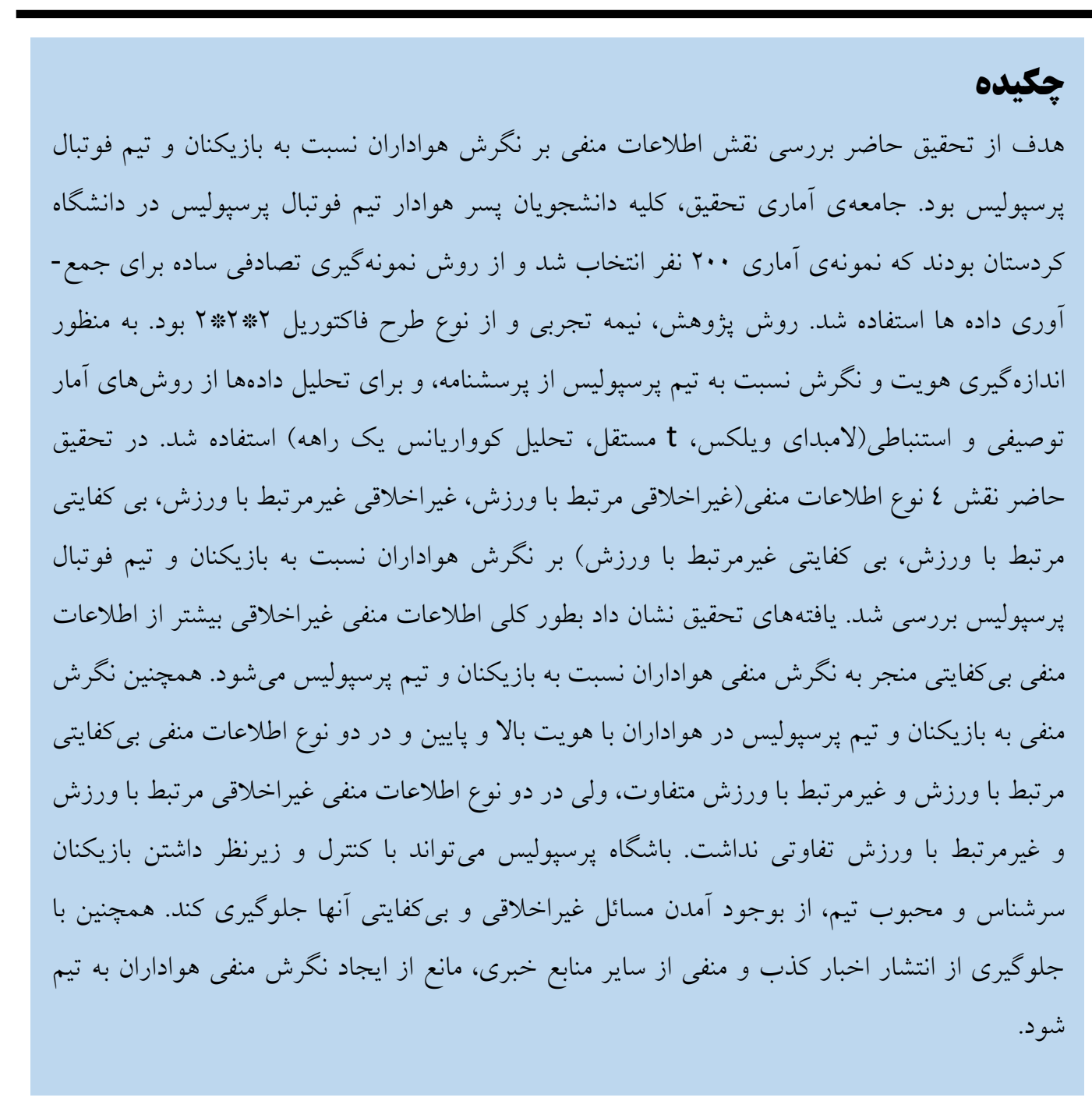

اطألات مقاله:

دريافت مقاله بهمن 97

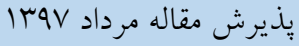

ث*زنويسنله مسئول:

ghasemi_m89@yahoo.com

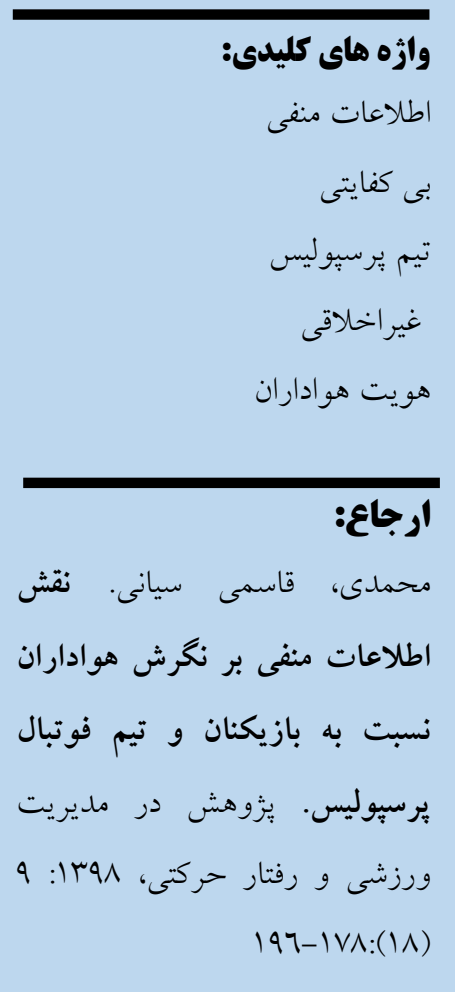

https://jrsm.khu.ac.ir/ 


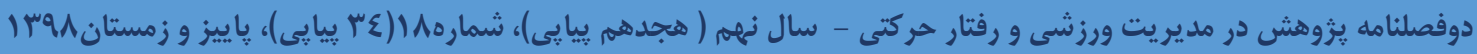

مقدمه

امروزه، مصرف كنند گان به طيف كستردهاى از رسانهها، از جمله رسانههاى سنتى و جديد براى كسب اطلاعات محصول دسترسى دارند. اين رسانهها براى سازمانها فرصتهاى جديدى را فراهم كردهاند كه به بازاريابى محصولات و خدمات خود بِيردازند و نكرش مثبت در رابطه با سازمان و محصولات خود ايجاد كنند اما وجود اين رسانهها، براى سازمانها مشكل ساز نيز شده است، بكونه ای كه مديريت كردن اطلاعات منفى در رابطه با محصولات و خدمات را سخت تر كرده( (1)، و ظهور رسانههاى اجتماعى به تشديد رسوايىهاى منتشر شده و ايجاد نخرش منفى منجر شده است( (اوץ). تحقيقات زيادى در ادبيات مديريت ورزش در بهبود بخشيدن به نخرش هواداران و تاثير آن بر رفتارهاى هوادار مانند افزايش حضور در ورزشخاه، فروش بليط و فروش لباس ورزشى تمركز كرده اند(ع). به همين ترتيب براى سازمان ها نيز بسيار ضرورى است كه با ايجاد نخرش مثبت در مشتريان مشتريانشان را وفادار نخه دارند(0). نخرش اشاره به جهت كيرى شناختى و عاطفى فرد با تو جه به برخى رفتارهاى محرك دارد(7). بنابر اين، نخرش نسبت به يكى تيم تحت عنوان ارزيابى كلى شركت كند كان از تيم ورزشى تعريف شده است(V). نحرش مصرف كند كان نسبت به يك سازمان يا نهاد ممكن است تحت تاثير اطلاعات بدست آمده از آن سازمان يا نهاد قرار بخيرد. تبليغات منفى مىتواند نخرش مشتريان به سازمان را تغيير دهد كه اين تغيير به صورت منفى خواهد بود(0). كلين' (1997) استدلال مى كند افراد هنخام ارزيابى يكى سازمان، ارزش و بهايى كه به اطلاعات منفى خود از آن نهاد مى دهند بيشتر از اطلاعات مثبت خود از آن نهاد يا سازمان است(م). همجنين نشان داده شده است كه اطلاعات منفى تاثير بيشترى بر ادراكات يا ارزيابىهاى افراد مى كذارد(9). كلين و

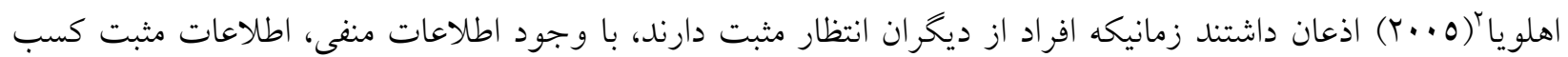
شده از آن افراد را ناجِيز مى يندارند(·) (1).

\section{اثر سرويز}

به منظور فهم بهتر تاثير تبليغات منفى بر هواداران ورزش "اثر سرريز" مىبايست مدنظر قرار بخيرد(ع). اهلوياً و

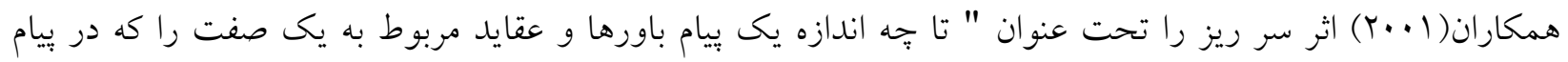
موجود نيست تحت تاثير قرار مىدهد" تعريف كرده اند(1). بنابراين، اثر سرريز مىتواند براى توضيح اين فرآيند كه نكرش افراد نسبت به يك نهاد مىتواند به يك نهاد مرتبط منتقل شود، توضيح داده مىشود(r|l). بر اين اساس، اخر يك

\footnotetext{
1. Klein

2. Klein \& Ahluwalia

3. Spillover Effect

${ }^{4}$. Ahluwalia
} 




ورزشكار مواد نيروزا مصرف كند، هوادار ورزش ممكن است بر اين باور باشد كه تيم مربوطه در استفادهُ ورزشكار از مواد نيروزا اغماض كرده است. بنابراين اخر برداشتها و نخرش هاى هو ادار نسبت به تيم ورزشى با وجود اينكه هيج اطلاعات منفى از تيم(در مقاله خبرى، كليِّ خبرى، رسانه هاى اجتماعى) ذكر نشده باشد، تغيير بيدا كند، بر اين اساس مىتوان كفت كه ورزشكار "سرريز" بيش از حد به تيم ورزشى دارد(ع). اخر جهه اثر سرريز مىتواند هم در زمينه اطلاعات منفى و هم در زمينه اطلاعات مثبت رخ دهد، قدرت قانع كنندگى اطلاعات منفى مى تواند مشكلاتى را براى نهاد مرتبط (تيم ورزشى) ايجاد كند(r) (I).

تحقيقات قبلى اثرات تبليغات منفى و سرريز را در زمينه ورزش مورد بررسى قرار داده اند و بيشتر در ارتباط بين شركتها و ورزشكاران صحه كذار كه درگير يك رسو ايى شده اند، تمركز كرده اند. بر طبق "اثر سرريز"، رويدادهاى منفى در رابطه با اشخاص مشهور صرفا نخرش مشتريان نسبت به خود آنها را تحت تاثير قرار نمىدهد بلكه ممكن است ارزيابى هاى آنها

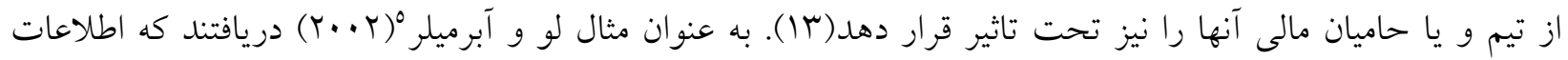
منفى، علاوه بر اينكه ورزشكاران صحه كذار را تحت تاثير قرار مىدهد، همجنين تاثير منفى در تصوير شركت دارد(ع ().

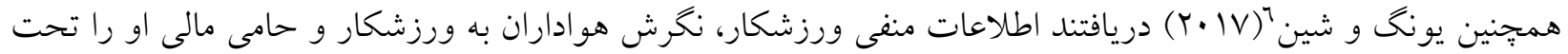
تاثير قرار مى دهد(1) . بنابراين، بسيار مهم است كه تاثير اطلاعات منفى بازيكنان بر رفتار هواداران تيم كه يك ارتباط روانى فردى نيز با تيم دارند، بررسى شود. در تحقيق حاضر تاثير اطلاعات منفى دو بازيكن سرشناس تيم يرسبوليس در نحرش هواداران به اين دو بازيكن و تيم برسبوليس بررسى خواهد شد. بكونه اى كه اين تاثير در رابطه با اطلاعات منفى غير اخلاقى و بى كفايتى، با نقش تعديل كنندكى اطلاعات منفى مرتبط و غيرمرتبط با ورزش، در بين هو اداران با هويت بالا

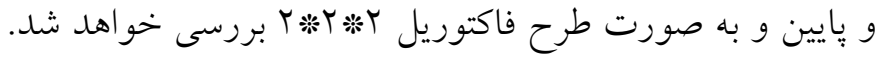

هنگام ارزيابى مردم از كسى يا جيزى، اطلاعات منفى نسبت به اطلاعات مثت، تاثير بيشترى بر تصميمگيرىهاى آنها مى كذارد(1) (1). اطلاعات منفى را مىتوان به دو دسته تقسيم كرد: اطلاعاتى كه مربوط به اخلاق است و اطلاعاتى كه شامل بى كفايتى و يا عدم قابليت است(IV). وجزيكى و همكاران(س (199r)، موارد بى اخلاقى را شامل مسائل اخلاقى كه شامل يكى عمل خبيثانه و نابكارانه است و جدال و ستيز با باورها و ارزشهاى اخلاقى بوجود مى آورد، دانستند در حالى كه مسائل كفايتى يا عملكردى به عملكرد عادى و يا عدم موفقيت براى مواجه شدن با استانداردهاى كيفيت مربوط مىشود. آنها همجنين دريافتند كه مردم با شدت بيشترى نقص و عيبهاى اخلاقى ديخران را نسبت به نقص و عيبهاى شايستكى

5. Louie \& Obermiller

6. Yoon \& Shin

7. Wojciszke

https://jrsm.khu.ac.ir/ 


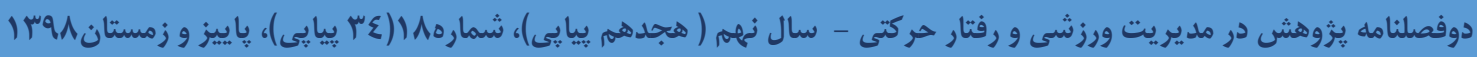

أنها قضاوت مى كنند. اين ارزيابى بر اين تصور استوار است كه انتظار مىرود همه مردم به معيارهاى اخلاقى خاصى كه منعكس كننده آداب و رسوم جامعه است، يايبند باشند. با اين حال، نقص صلاحيت مجاز است، جرا كه هر كس داراى

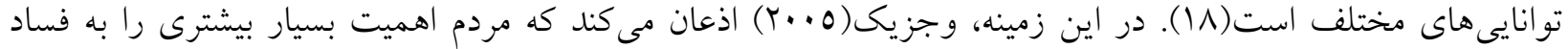
ديخران نسبت به عملكرد ضعيف آنها قائل هستند(19).

بسيارى از مطالعات نشان داده اند كه رفتار مصرف كننده(هوادار) تحت تاثير سطوح هويت تيمى است(Y (Y). نظريه هويت اجتماعى توضيح مى دهد كه مردم خود را تحت عنوان يك بخش و وابسته به كروههاى اجتماعى مختلف تعريف مى كنند. هويت با يك تيم ورزشى، تحت عنوان هويت فرد از نظر دلبستخى به يك تيم ورزشى تعريف مىشود، بخونهاى كه تيم ورزشى به بخشى جدايى نايذير از هويت شخص تبديل مىشود(·). هويت قوى با يك تيم ورزشى جنبه هاى مختلف رفتار هوادار را تحت تاثير قرار مى دهد؛ بخصوص با توجه به مقدار زمان؛ يول و تلاشى كه يك هوادار در يك تيم سرمايه كذارى مى كند، مانند حضور در بازى و مقدار يولى كه يك شخص براى كالاهاى داراى مجوز صرف مى كند( (T). نظريه هويت اجتماعى بيان مى كند كه مردم مى خواهند در موفقيت ديخران زمانيكه آنها را در رسيدن به آن موفقيت كمك كرده اند، سهيم باشند. از طرف ديخر، مردم سعى مى كنند با زور و اجبار از ارزيابى هاى منفى يا عدم موفقيت ديخران فاصله بخيرند. از اين رو، مى توان انتظار داشت كه هويت هوادار با يك تيم ورزشى قضاوت آنها از مسائل منفى مربوط به تيمهاى ورزشى را تحت تاثير قرار دهد. بر اساس نظريه هويت اجتماعى، معتقديم كه اخر هواداران هويت بالايى با يك

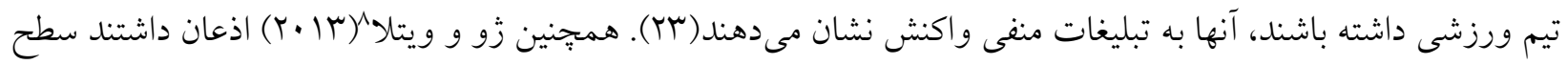
هويت هو اداران نسبت به بازيكنان و تيمهاى ورزشى در واكنش آنها به اطلاعات منفى و رسو ايىهاى بازيكن و تيم متفاوت است، بخونه اى كه در مواجه با اين اطلاعات منفى، نخرش و رفتارهاى متفاوتى از خود نشان مى دهند(Y). هر عملى انخيزه خاص خود را دارد. افراد بطور غريزى به دنبال اين هستند كه از انخيزه افراد از انجام يك عمل خاص آكاه شوند(T0). مردم رفتار افراد را به عنوان يك مسير غيرمستقيم به افكار خود مشاهده مى كنند، و اين جنين استتتاج

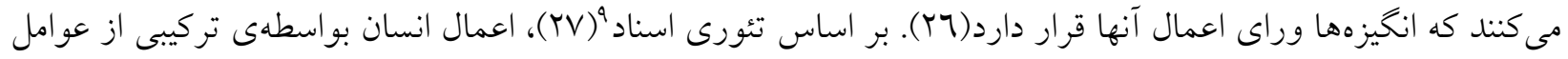
مختلف شكل مى گيرد، دانستن اين نكته كه انخيزه هاى مختلف و متنوعى براى رفتارهاى افراد وجود دارد، جارجوبى را براى نسبت دادن اعمال ديخران به علتهاى بنيادى مختلف فر اهم مى كند(Y0). هيدر" (1901) همجنين اذعان مى كند كه رفتار انسان شامل r بعد داخلى و خارجى است، عوامل داخلى، رفتارهاى عمدى را شامل مىشوند، در حاليكه عوامل

\footnotetext{
8. Zhou \& Whitla

${ }^{9}$. Attribution Theory

${ }^{10}$. Heider
}

https://jrsm.khu.ac.ir/ 


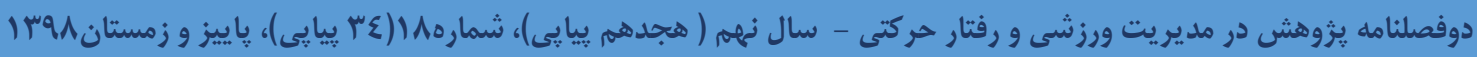

خارجى رفتارهاى غير عمدى را دربرمى گيرند(YV). وينر "و همكاران(9V9 (19) ييشنهاد كردند كه وقتى افراد از يك رويداد منفى مطلع مى شوند، آنها به دنبال علت آن رويداد مىروند. از نقطه نظر رفتار مصرف كننده، افراد زمانيكه بحران بوجود آمده در يك شركت را ناشى از خود شركت بدانند، مسئوليت شركت را براى بحران بوجود آمده مورد ارزيابى قرار

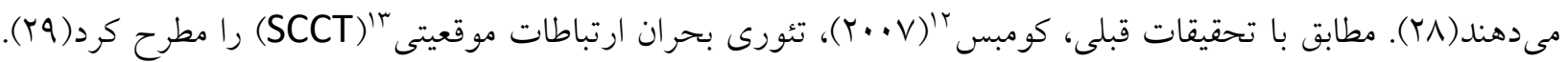
نظريه اسناد، اساس ر ا تشكيل مىدهد. بر اساس سطح مسئوليت اعمال انسان، مردم براى يك عمل مثبت هنگامى كه آن عمل به عمد باشد قدردانى بيشترى مى كنند نسبت به زمانيكه آن عمل بطور ناخواسته باشد، و به همين ترتيب نتايج منفى بيشتر سرزنش مىشوند زمانى كه آنها عمدى باشد (·r).

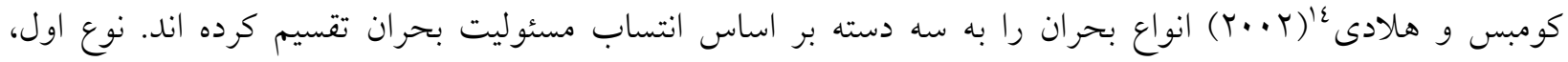
"قربانيانها" (به عنوان مثال، بلاياى طبيعى مانند زلزله كه غير قابل اجتناب است)، داراى نسبت بسيار ضعيف از مسئوليت بحران كه سازمان به عنوان يك قربانى از اين رويداد درى مىشود. در نوع دوم، "حوادث ناخواستهج" (به عنوان مثال، خطاهاى فنى يا محصولات معيوب)، داراى نسبت حداقل از مسئوليت بحران كه مردم بر اين باورند كه اين سازمان قصد انجام دادن اين حادثه را نداشته و يا نمىتوانسته بر آن كنترلى داشته باشد. بكونه اى كه در مورد يك محصول معيوب، مصرف كنندكان قبول مى كنند كه سيستم فرايند كيفيت به طور كامل نمىتواند كالاى معيوب را تشخيص دهد. نوع سوم، "عمدى vا" (به عنوان مثال، حوادث ناشى از خطاى انسانى يا نقض قانون توسط مديران)، داراى نسبت بسيار شديد مسئوليت بحران است، كه مردم معتقدند حادثه قابل بيشخيرى بوده است. اين جارجّوب به فرايند شكل گيرى نخرش

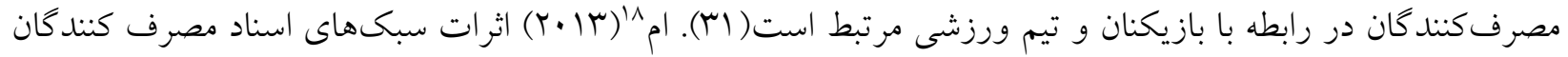
در ارزيابى هاى برند تاييد شده را بررسى كردند. در اين مطالعه، مصرف كنند كانى كه اطلاعات منفى در رابطه با بازيكن مشهور را به عنوان يك مورد موقعيتى درى كردند، نخرش منفىترى به برند و قصد خريد نسبت به كسانى كه اين مورد را به عنوان غيرموقعيتى درك كردند، نشان دادند(Y)(T). مطالعه ديخرى نشان داد قابليت كنترل يك شركت در ميزان تقصير در يك حادثه، ياسخ مصرف كنندگان به تبليغات منفى را تحت تاثير قرار مىدهد. بررسى با استفاده از يك سناريو كه در

\footnotetext{
11. Weiner

12. Coombs

13. Situational crisis communication theory

14. Coombs \& Holladay

15 . victims

${ }^{16}$. unintended accidents

17 . intentional

18. Um
} 


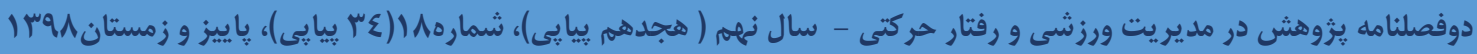

رابطه با رسو ايى سلامت مواد غذايى انجام شد، نشان داد ارزيابى مصرف كنندگان از شركت درگير، با سطح درى شده از كنترل (براى مثال، جِقدر اين شركت در رويداد منفى بوجود آمده كنترل داشته است؟) ميانجى شد(Y0). در برتو تحقيقات قبلى در نظريه اسناد، منطقى است نتيجه بخيريم كه ستاره هاى ورزشى نيز ممكن است مسئوليت بيشترى براى حوادث غير مرتبط با بازى داشته باشند، در حالى كه آنها مسئوليت كمترى براى رويدادهاى مربوط به بازى دارند. به ويزه، اخر يك ستاره ورزشى در طول يك بازى مصدوم شود، هواداران رفتار ستاره ورزشى را غير قابل كنترل در نظر مى كيرند و جنين درك مى كنند كه بازيكن حداقل مسئوليت را در اين وضعيت داشته است، به جاى اينكه او را سرزنش كنند. در مقابل، اكر حادثه ایى مشابه در خارج از يك بازى رخ دهد (به عنوان مثال، ستاره هاى ورزشى كه در يك حادثه خارج از ورزش مصدوم مى شوند)، هواداران اين موضوع را به عنوان يك وضعيت قابل كنترل درى مىكنند، و بر اين اعتقادند كه اگر ورزشكار مواظب بود، ممكن بود جنين اتفاق منفى رخ ندهد. بر اساس نظريه فوق و يافتها، مى توان جنين انتظار داشت كه هواداران، ستاره ورزشى را به عنوان مسئول بيشتر در رابطه با وقايع منفى در شرايط غيرمرتبط با ورزش نسبت به شرايط مرتبط با ورزش در نظر مى گيرند.

\section{روش شناسى بذوهش}

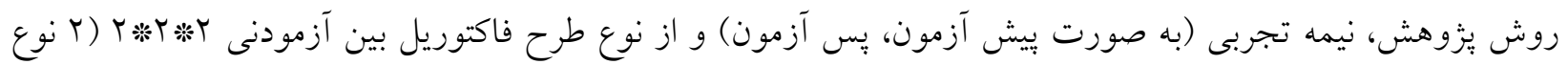
تبليغات منفى غير اخلاقى و بى كفايتى، r نوع هويت بالا و بايين، r نوع اطلاعات منفى مرتبط و غيرمرتبط با ورزش) بود. طرح فاكتوريل، از يِيجيده ترين طرح هاى تجربى و نيمه تجربى در مطالعات مديريت است و اين امكان را فراهم مى سازد كه تاثيرهاى دو يا جند دستكارى را بر متغير وابسته به طور همزمان بيازماييم. همجنين، در اين نوع طرح مى توان اثرات دو يا جند متغير مستقل و نيز تعامل ميان آنها را اندازه كيرى كرد؛ به همين دليل، طرح فاكتوريل، كار آمدتر از جندين طرح تصادفى تكى عاملى است(سٓ). يزوهش حاضر از نظر هدف كاربردى است. جامعه آمارى تحقيق، كليه دانشجويان

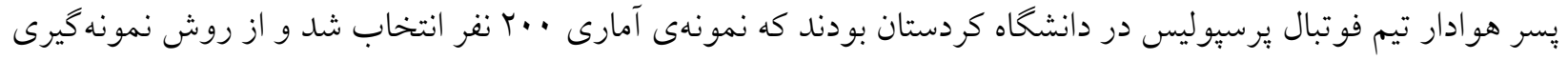
تصادفى ساده براى جمع آورى دادهها استفاده شد. با توجه به طرح فاكتوريل (جدول ()، 1 شرايط متفاوت وجود دارد، كه بر اين اساس از •r نفر نمونه، تعداد 177 نفر تا بايان يُزوهش حاضر به همكارى شدند كه اين تعداد به صورت تصادفى به ^ گروه تقسيم و در هر كدام از اين ^ شرايط، به صورت تصادفى قرار خرفتند. 


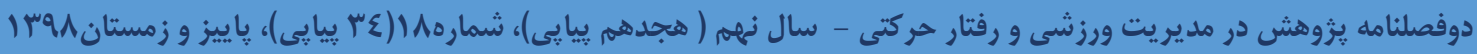



\begin{tabular}{|c|c|c|c|c|c|c|}
\hline \multicolumn{4}{|c|}{ ييش آزمون } & مداخله & \multicolumn{2}{|c|}{ بس آزمون } \\
\hline هويت & نوع ارتباط با ورزش & بنحرش نسبت به بهنان & نكرش نسبت به & نوع اطلاعات & بحرش نسبت به بهن & نكرش نسبت \\
\hline بالا & n=rn غيرمرتبط & $\varepsilon / T_{0}$ & $\varepsilon / \pi$ & \multirow{4}{*}{ غيراخلاقى اطلى منفى } & $r / \varepsilon r$ & $r / 0$ \\
\hline لَايين & غيرمرتبط n=r. & $r / 10$ & $\varepsilon / 19$ & & $1 / 9$. & $1 / 7 \mathrm{~V}$ \\
\hline بالا & مرتبط & $\varepsilon / \Gamma r$ & $\varepsilon / \Lambda V$ & & $r / .7$ & $r / 0 \varepsilon$ \\
\hline لِايين & . & $r / 91$ & $\varepsilon / T_{0}$ & & $r / \varepsilon r$ & $r / M r$ \\
\hline بالا & nير n=r غرتبط & $\varepsilon / \mu r$ & $\varepsilon / \varepsilon 0$ & \multirow{4}{*}{ اطلاعات منفى كفايتى } & $\varepsilon / 1 r$ & $\varepsilon / 17$ \\
\hline بֶايين & غيرمرتبط n=r. & $r / 09$ & $r / 90$ & & $r / 20$ & r/or \\
\hline بالا & |مرتبط & $\varepsilon / T \varepsilon$ & $r / T r$ & & $r / 9 V$ & $r / v q$ \\
\hline بإيين & • مر تبط & $r / r q$ & $r / \Lambda r$ & & $r / 07$ & $r / .1$ \\
\hline
\end{tabular}

هر يك از گروههاى تجربى به روش زير داستان دريافت كردند:

اطلاعات منفى غيراخلاقى مرتبط با ورزش: داستان به اين صورت است كه دو بازيكن تيم برسبوليس در يكى از بازيهاى جام باشخاههاى آسيا دويينگ كرده و دويينگ آنها بعد از آزمايش مثبت اعلام شده است. اطلاعات منفى غيراخلاقى غيرمرتبط با ورزش: داستان به اين صورت است كه دو بازيكن تيم برسبوليس به علت استفاده از مشروبات الكلى و حضور در يارتى مختلط دستخير شده اند. اطلاعات منفى بى كفايتى مرتبط با ورزش: داستان به اين صورت است كه دو بازيكن تيم برسبوليس در تمرينات اين تيم دجار مصدوميت شده و ادامه بازيهاى اين تيم را از دست داده اند. اطلاعات منفى بى كفايتى غير مرتبط با ورزش: داستان به اين صورت است كه دو بازيكن تيم برسبوليس در جريان تبليغ محصول دجار مصدوميت شده و ادامه بازيهاى اين تيم را از دست داده اند.

روش تردآورى اطلاعات

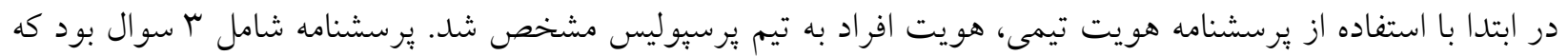
در طيف ه گزينهاى ليكرت تنظيم شده بود، با توجه به يرسشنامه حاضر افراد با توجه به ياسخهاى خود نسبت به ميانخين



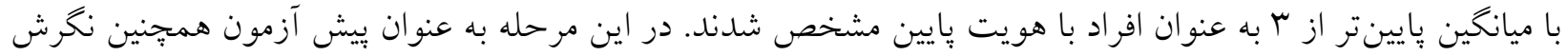

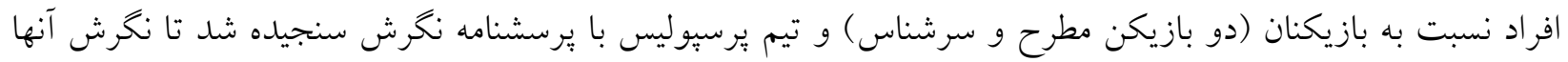
نسبت به بازيكنان و همجنين تيم يرسيوليس مشخص شود. براى اينكه بتوان ياسخ دهند كان را شناسايى كرد تا در هنگام






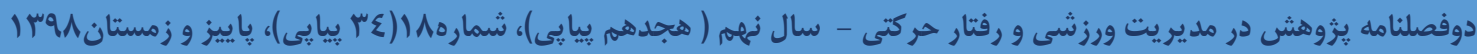

هويت تيمى و نخحش يُاسخ داده بودند، به صورت تصادفى و با توجه به هويت آنها به م دسته تقسيم و در طرح فاكتوريل

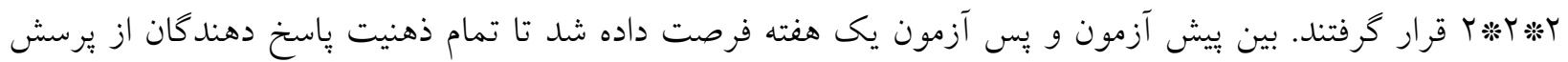

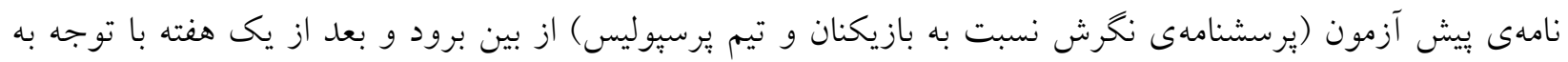

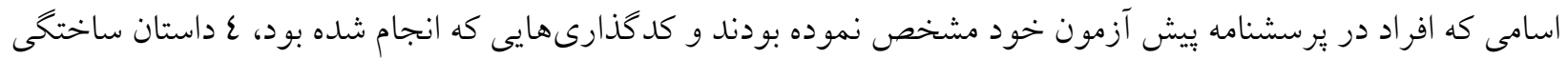
(داستان اطلاعات منفى غيراخلاقى مرتبط با ورزش، داستان اطلاعات منفى غيراخلاقى غيرمرتبط با ورزش، داستان اطلاعات منفى بى كفايتى مرتبط با ورزش و داستان اطلاعات منفى بى كفايتى غيرمرتبط با ورزش، در افراد با هويت بالا و

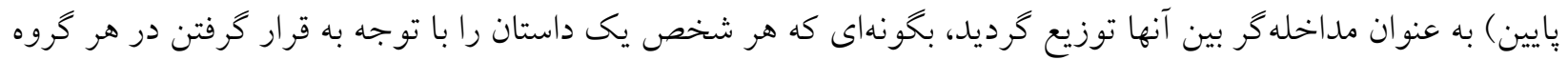


به كد گذارى انجام شده در يرسشنامهها، يرسشنامه يُ آزمون (نخرش نسبت به بازيكنان و تيم يرسيوليس) در بين آنها توزيع كرديد. لازم به ذكر است كه در يايان تحقيق به هر يك از نمونهها اعلام شد كه داستانها ساختكى بود.

\section{ابزار اندازه تيرى}

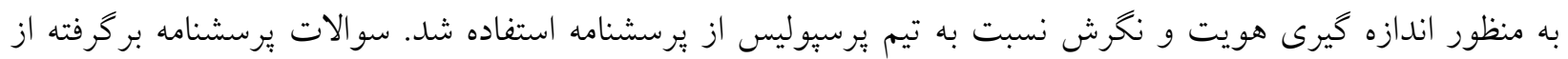

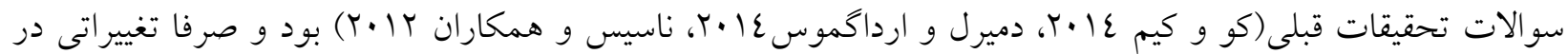
مقياس اندازه گيرى بعضى از مولفهها داده شد(جدول Y). براى اطمينان از روايى صورى برسشنامهها و داستانهاى ساختكى،

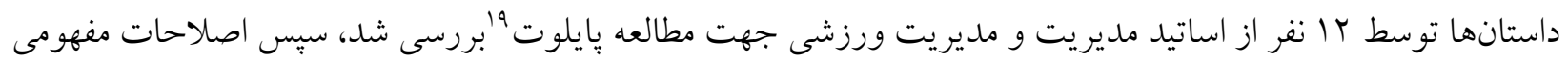

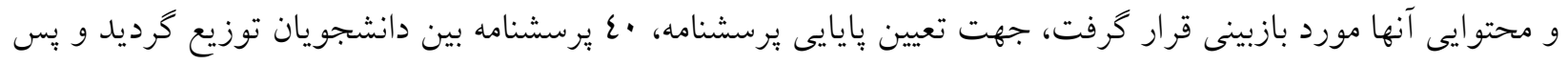
از جمع آورى دادهها ميزان آلفاى كرونباخ آن تعيين شد.

${ }^{19}$ pilot

https://jrsm.khu.ac.ir/ 


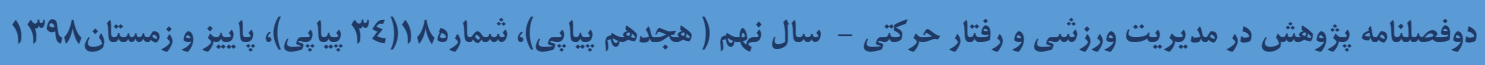

جدول r: بايايى، منابع و سوالات هر يك از مولفهها

\begin{tabular}{|c|c|c|c|}
\hline منابع & پِايايى(آلفاى كرونباخ) & سوالات & مولفه \\
\hline 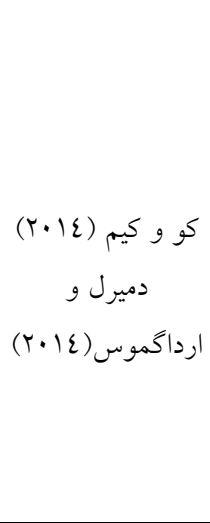 & •/AT & 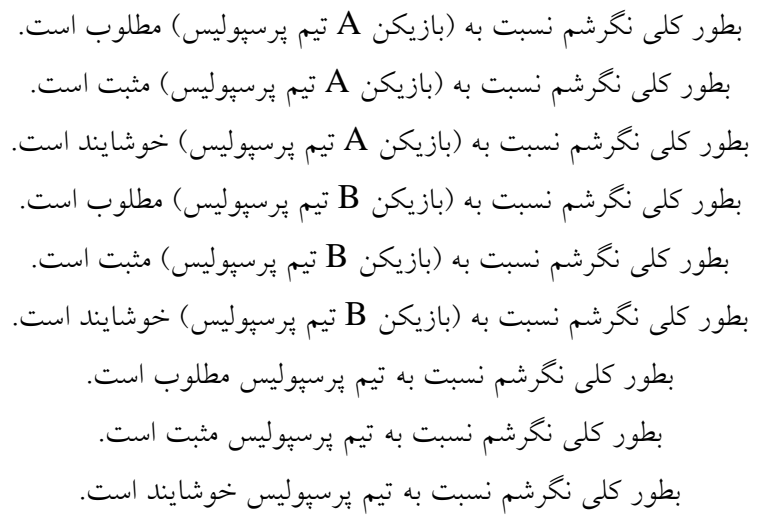 & 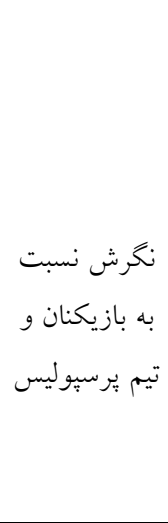 \\
\hline 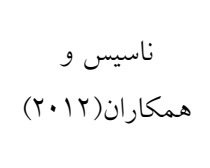 & $\cdot / N V$ & 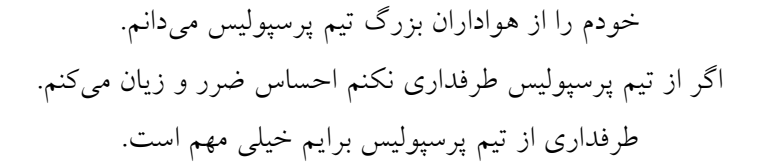 & هويت تيمى \\
\hline
\end{tabular}

\section{جمع آورى داده ها}

به منظور تحليل داده ها از نرم افزار آمارى SPSS 23 و از روشهاى آمار توصيفى(فراوانى، درصد، ميانخين و انحراف معيار) و استنباطى (لامبداى ويلكس، t مستقل، تحليل كوواريانس يكى راهه) استفاده شد.

يافته ها

جدول: وضعيت جمعيت شناختى نمونهها

\begin{tabular}{|c|c|c|c|}
\hline درصد & تعداد & \multicolumn{2}{|c|}{ متغيرها } \\
\hline$\wedge \Sigma / q$ & $|\varepsilon|$ & مجرد & \multirow{3}{*}{ تاهل } \\
\hline $10 / 1$ & ro & متاهل & \\
\hline$\cdot 11 \ldots$ & 177 & جمع & \\
\hline$\varepsilon / \Lambda$ & $\wedge$ & زير •r سال & \multirow{5}{*}{ سن } \\
\hline$O V / T$ & 90 & IOH & \\
\hline$\mu / v$ & 07 & $r \cdot r$ r & \\
\hline$\varepsilon / r$ & v & بالاى .r. & \\
\hline$\cdot 11 \cdots$ & 177 & جمع & \\
\hline $07 / 7$ & $9 \varepsilon$ & كارشناسى & \multirow{4}{*}{ مقطع } \\
\hline$r V / q$ & ז & كارشناسى ارشد & \\
\hline $0 / 2$ & 9 & دكترى & \\
\hline$\cdot 11 \cdots$ & 177 & جمع & \\
\hline
\end{tabular}

https://jrsm.khu.ac.ir/ 
جدول ع: نتايج آزمون لامبداى ويلكس

\begin{tabular}{|c|c|c|c|c|c|c|}
\hline توان آمارى & مجذور اتا & سطح معنادارى & فرجه آزادى & FسبتF & مقدار & متغيرها \\
\hline.$/ 7.1$ &.$/ T V$ &.$/ \cdot 7 \varepsilon$ & $r$ & $r / 017$ & . & بازيكن (ييش آزمون نسبت به \\
\hline$\cdot / 110$ & $\cdot / r \cdot \cdot$ &.$/ .14$ & $r$ & $\varepsilon / \cdot V \varepsilon$ & $\cdot / \wedge \cdot \cdot$ & نكرش نسبت به تيم(ييش \\
\hline.$/ 91$. & $\cdot \pi \cdot 1$ & $\cdot / \cdots$ & 9 & $\varepsilon / T \varepsilon$. & $.10 \cdot 9$ & داستان \\
\hline$\cdot / A V Q$ &.$/ T Y V$ &.$/ \cdots 0$ & 9 & $\varepsilon / \lambda \cdot \varepsilon$ & $\cdot / \mathrm{Vr}$ & هويت \\
\hline.$/ 770$ &.$/ .91$ & $\cdot / \cdot v 7$ & 9 & $1 / N 9 \varepsilon$ & $\cdot / N r \varepsilon$ & داستان*شهويت \\
\hline
\end{tabular}

جدول ب نتايج آزمون لامبداى ويلكس براى تاثيرات جندمتغيره نمره بيش آزّمون نخرش و داستان و هويت را بر نمره پِ

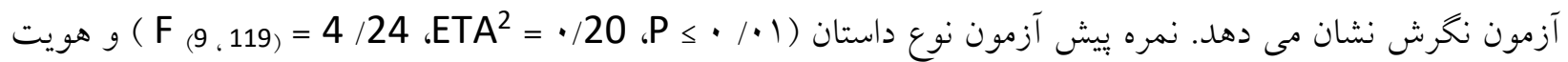
(F تاثير معنى دارى داشته است. ساير متغيرها ( نمره بيش آزمون نخرش بازيكن، نخرش تيمى و تعامل داستان - هويت) تاثير معنى دارى نداثته است(P (P) 0/05).

جدول0: نتايج آزمون تحليل واريانس براى بررسى تاثيرات تك متغيره بر نخرش نسبت به بازيكن و تيم

\begin{tabular}{|c|c|c|c|c|c|c|c|c|}
\hline آمارى & مجذور اتا & معنى دارى & $F$ & مجذيانكين & $\mathrm{DF}$ & مجذورات & متغير وابسته & \\
\hline $\begin{array}{l}. / 990 \\
. / 907 \\
\end{array}$ & $\begin{array}{l}\text {. MOV } \\
. / T V Y\end{array}$ & $\begin{array}{l}\cdot / \cdots \\
. / \cdot 1\end{array}$ & $9 / \varepsilon \varepsilon \wedge$ & $\begin{array}{l}\text { T/79T } \\
\text { E/ONT }\end{array}$ & $r$ & $\begin{array}{l}r \cdot / \cdot v q \\
1 r / V \varepsilon 7\end{array}$ & نحرش نسبت به بازيكن(يس آزمون) & داستان \\
\hline - /ArO & $\cdot / / \varepsilon 7$ &.$/ \cdots$ & $\begin{array}{l}0 / .47 \\
N / V \cdot \varepsilon\end{array}$ & $\begin{array}{l}\text { r/07V } \\
7 / Y 77\end{array}$ & 1 & $\begin{array}{l}r / 07 V \\
T / Y 77\end{array}$ & نحرش نسبت به بازيكن (يس آزمون) & هويت \\
\hline
\end{tabular}






جدول س، نتايج آزمون تحليل واريانس براى بررسى تاثيرات تك متغيره بر نخرش نسبت به بازيكن و تيم را نشان مى دهد. يافته ها بيانكر اين است كه نوع داستان بر هر دو بعد نخرش(بازيكن، تيم) اثر گذار بوده است. دامنه اندازه گيرى بين ب/ • تا حس/• است. اثر هويت بر بعد بازيكن(9) = ETA2

جدول7ا: مقايسة ميانخين ياسخ هاى پيس آزمون هو اداران در معرض اطلاعات منفى غير اخلاقى و بى كفايتى در نخرش نسبت به بازيكنان و تيم يرسبوليس

\begin{tabular}{|c|c|c|c|c|}
\hline انحر اف معيار & ميانكين & تعداد & 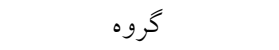 & متغير \\
\hline $1 / 1 \varepsilon$ & $T / N \varepsilon$ & $\Delta r$ & اطلاعات منفى غير اخلاقى & \multirow{2}{*}{ نخرش نسبت به بازيكنان تيم يرسيوليس } \\
\hline$\cdot / N r$ & $r / v q$ & $\lambda r$ & اطلاعات منفى بى كفايتى & \\
\hline $1 / r \varepsilon$ & $r / \cdot \cdot$ & $\wedge r$ & اطلاعات منفى غير اخلاقى & \multirow{2}{*}{ نحرش نسبت به تيم يرسيوليس } \\
\hline$\cdot / \mathrm{Vq}$ & $r / 7 r$ & $\Lambda \mu$ & اطلاعات منفى بى كفايتى & \\
\hline
\end{tabular}

جدول V: نتايج آزمون T مستقل و لوين

\begin{tabular}{|c|c|c|c|c|c|c|c|c|c|}
\hline \multicolumn{2}{|c|}{ تفاضل در فاصله اطمينان 90٪ } & \multicolumn{4}{|c|}{  } & \multicolumn{2}{|c|}{ آزمون لوين } & & \multirow{2}{*}{ متغير } \\
\hline Upper & Lower & ميانكَينها & معنادارى سطح & آزادى درجه & Tآماره T & معنادارى سطح & $\mathrm{F}$ & & \\
\hline$-\cdot 107$ & $-1 / 0$ ry & $-1 / \cdot \varepsilon$ & $\cdot / \cdot 1$ & $17 \varepsilon$ & $-\varepsilon / \pi q$ & $\% r$ & $1 \cdot / 91$ & $\begin{array}{c}\text { واريانس هاوى } \\
\text { وانسا }\end{array}$ & به بـرش نسبت \\
\hline$-\cdot 100$ & $-1 /$ orv & $-1 / \cdot \varepsilon$ & $\cdot / \cdot 1$ & $171 / r$ & $-\varepsilon / \pi q$ & & & عدم تساوى & يرسيوليس \\
\hline$-\cdot / 1 \cdot \varepsilon$ & $-1 / 17 \varepsilon$ & $-\cdot / 7 r$ &.$/ \cdot r$. & $17 \varepsilon$ & $-4 / T_{A}$ & $\cdot / \cdot 1$ & $10 / 27$ & واريانس ها & نغرش نسبت \\
\hline$-\cdot / 1 \cdot r$ & $-1 / 170$ & $-\cdot / \pi$ & $\cdot / \cdot r \cdot$ & $171 / 1 V$ & $-r / r q$ & & & عدام تساوى & يرسيوليس \\
\hline
\end{tabular}




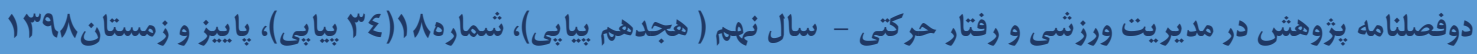

با توجه به جداول ه و 7 و با توجه به سطح معنادارى آزمون لوين كه براى هر دو متغير كمتر از 0• • است متوجه مىشويم كه واريانس ها در دو كروه اطلاعات منفى غيراخلاقى و بى كفايتى در هر دو متغير (نكرش نسبت به بازيكنان و

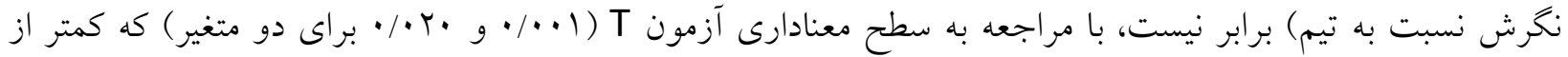
••• • است نتيجه مى گيريم كه تاثير اطلاعات منفى در دو گروه (اطلاعات منفى غيراخلاقى و اطلاعات منفى بى كفايتى) در نكرش نسبت به بازيكنان و تيم تيرسوليس تفاوت معنادارى دارد و با توجه به ميانخين دو كروه در دو متغير يى مى بريم هوادارانى كه در معرض اطلاعات منفى غيراخلاقى قرار كرفته اند نخرش منفىترى نسبت به بازيكنان و همينطور تيم برسبوليس دارند.

جدولم: نتايج آزمون مقايسه هاى زوجى

\begin{tabular}{|c|c|c|c|c|c|c|c|}
\hline \multicolumn{2}{|c|}{ تفاضل در فاصله اطمينان 90٪ } & \multirow{2}{*}{ Sig } & \multirow{2}{*}{ خطان } & \multirow{2}{*}{ تفاضل } & \multirow[b]{2}{*}{ داستان(J) } & كروه & \multirow{2}{*}{ متغير وابسته } \\
\hline $\begin{array}{l}\text { Upper } \\
\text { Bound }\end{array}$ & $\begin{array}{l}\text { Lower } \\
\text { Bound }\end{array}$ & & & & & داستان (I) & \\
\hline- - TYO & $-Y / \cdot V I$ & $\cdot / \cdot r$ &.$/ \mu 1 \Lambda$ & $-1 / 191$ & منفى بى كفايتى مرتيط & \multirow{3}{*}{ منفى غير اخلاقى } & \multirow{5}{*}{ بازيكرش نسبت به (يس } \\
\hline$\cdot / A V r$ & $-\cdot \cdot / \wedge T \Lambda$ &.$/ 110$ & • & $\cdot \cdot \cdot r$ & منفى غير اخلاقى غيرمرتبط & & \\
\hline$-\cdot / T V \Lambda$ & $-Y / \cdot \sum r$ & $\cdot / \cdot \varepsilon$ & $\cdot \pi r$. & $-1 / 170$ & منفى بى كفايتى غيرمرتبط & & \\
\hline$r / \varepsilon \Lambda$ & $\cdot /$ ror & $\because \cdot \cdot r$ & $\cdot / r \cdot 9$ & $1 / \pi \cdot 1$ & منفى غير اخلاقى غيرمرتبط & \multirow{2}{*}{ منفى بى كفايتى } & \\
\hline . MAY & $-\cdot / 1 / 10$ & $\cdot / \cdot 1$ & $\cdot / \pi \cdot 9$ & $-\cdot \pi \mu$. & منفى بى كفايتى غيرمرتبط & & \\
\hline .1040 & $-1 / K Y T$ & $\cdot / \cdot 1$ & $\cdot / \pi Y 1$ & $-\cdot / \mu \varepsilon\rceil$ & منفى بى كفايتى مرتيط & \multirow{3}{*}{ منفى غير اخلاقى مرتبط } & \multirow{5}{*}{ تيمرش نسبت به آزمون) } \\
\hline $1 / \varepsilon \wedge V$ & $-\cdot / r \backslash \Lambda$ & $\cdot \pi V \varepsilon$ & $\cdot \pi r$. & $\cdot / 7 \cdot 9$ & منفى غير اخلاقى غيرمرتبط & & \\
\hline$\cdot / 119$ & $-1 / 011$ & $\cdot \pi / r$ & - MYY &.$- / 797$ & منفى بى كفايتى غيرمرتبط & & \\
\hline $1 / 1 \cdot 9$ &.$/ 1 \cdot 1$ & $\cdot / \cdot r$ & $\cdot / \pi 11$ &.$/ 900$ & منفى غير اخلاقى غيرمرتبط & منفى بى كفايتى & \\
\hline $.10 \cdot 0$ & $-1 / 4 \cdot 7$ & $\cdot / \cdot 1$ & $\cdot \pi / r$ & $-\cdot / \pi 01$ & منفى بى كفايتى غيرمرتبط & مرتبط & \\
\hline
\end{tabular}

جدول V نتايج آزمون مقايسه هاى زوجى بنفرونى را نشان مىدهد. همانطور كه قابل مشاهده است در نخرش نسبت به بازيكنان و تيم يرسيوليس، تفاوت كروه داستان منفى غيراخلاقى مرتبط با غيراخلاقى غيرمرتبط، غيرمعنادار (0 • • P)، ولى تفاوت كروه داستان منفى بى كفايتى مرتبط با بى كفايتى غيرمرتبط معنادار (0 • • P) است. 


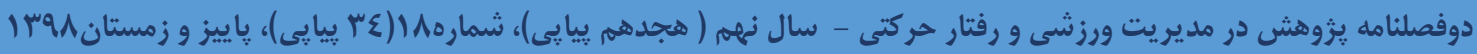

جدوله: آزمون مقايسه هاى زوجى افراد با هويت بالا و يايين در نخرش به تيم و بازيكن

\begin{tabular}{|c|c|c|c|c|c|c|c|}
\hline \multicolumn{2}{|c|}{ تفاضل در فاصله اطمينان 90٪ } & \multirow{2}{*}{ SIG } & \multirow{2}{*}{ استاندارد } & \multirow{2}{*}{$\begin{array}{c}\text { ميانكين I- تفاوت } \\
\text { IJ }\end{array}$} & \multirow{2}{*}{ هويت (J) } & \multirow{2}{*}{ هويت (I) } & \multirow{2}{*}{ متغيرهاى وابسته } \\
\hline $\begin{array}{l}\text { Upper } \\
\text { Bound }\end{array}$ & $\begin{array}{l}\text { Lower } \\
\text { Bound }\end{array}$ & & & & & & \\
\hline $1 / . r r$ & .1 .07 & $\cdot / \cdot r q$ & 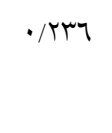 & $.1049 *$ & بايين & بالا & بكرش نسيت بـ به آزمون) \\
\hline $1 / 1 \vee q$ & . / TrE &.$/ \cdot 0$ & 㑭 & $\cdot / N \cdot r^{*}$ & 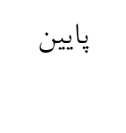 & بالا & نحرش نسبت به تيم \\
\hline
\end{tabular}

جدوله، آزمون مقايسه هاى زوجى هواداران با هويت بالا و يايين را در نخرش نسبت به بازيكنان و تيم يرسبوليس نشان

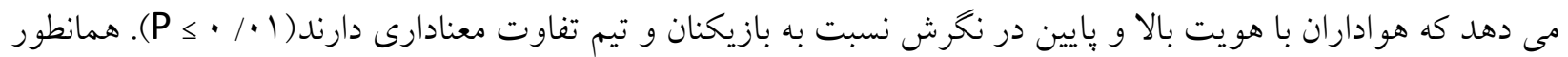
كه با مقايسهى تفاوت ميانخين دو گروه هويت بالا و پيايين قابل مشاهده است افراد با هويت بالا در نخرش نسبت به

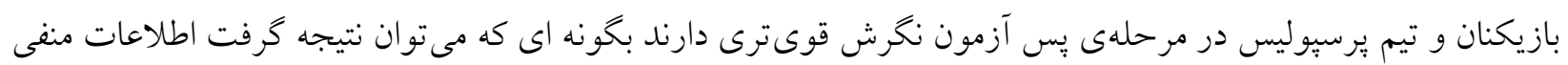
غير اخلاقى و بى كفايتى در نخرش هواداران با هويت بالا تاثير بسيار كمترى نسبت به هواداران با هويت بايين داشته

\section{بحث و نتيجه تيرى}

هدف از تحقيق حاضر بررسى نقش تبليغات منفى بر نخرش هواداران نسبت به بازيكنان و تيم فوتبال برسبوليس بود.



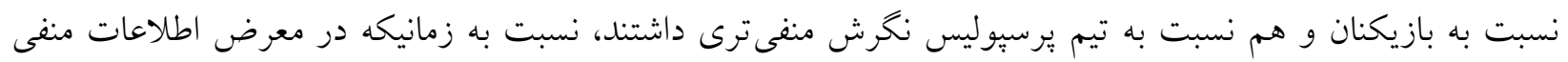
بى كفايتى قرار گرفتند. از نتايج جالب تحقيق، انتقال يافتن نخرش منفى از بازيكنان به تيم است، بخونهاى كه هواداران با

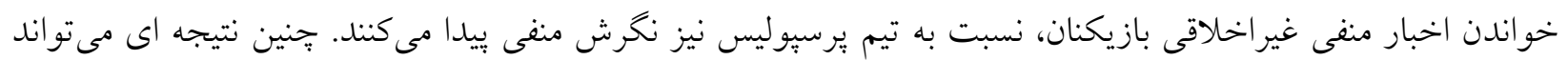
وظيفه بازيكنان تيم را سنخين تر كند كه بيشتر مراقب رفتار و اعمال خود در سطح جامعه باشند. اين وظيفه در رابطه با بازيكنان محبوب و سرشناس بيشتر است. بطوريكه در تحقيق حاضر نيز در رابطه با دو بازيكن محبوب و سرشناس تيم برسبوليس اين نتايج حاصل شد. همانطور كه وجزيك (0. ㄷ) نيز اذعان داشت، مردم به فساد نسبت به عملكرد اهميت بيشترى مى دهند و واكنش بيشترى را نسبت به مسائل اخلاقى از خود نشان مى دهند. جامعه ايران نيز به دليل فرهنگ و ارزش هاى خاص خود كه در بين اكثريت افراد جامعه وجود دارد، به مسائل اخلاقى واكنش نشان مىدهند. بطوريكه 


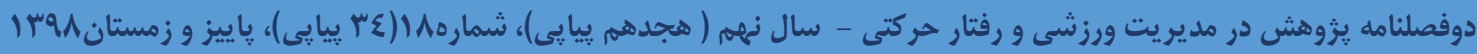

هو اداران فوتبال نيز از اين قضيه استثنا نيستد و آنها نسبت به مسائل اخلاقى تيم محبوب و همينطور بازيكنان بىتفاوت نيستند. از قسمت اول تحقيق مىتوان جنين برداشت كرد كه هواداران دوست دارند هوادار تيمى باشند كه بازيكنان آن تيم از نظر مسائل اخلاقى تصوير خوبى در جامعه داشته باشند. بحث مسائل غير اخلاقى و فساد مى تواند در بسيارى از كشورها مورد توجه قرار بخيرد بطوريكه در كشور ما نيز اين قضيه مستثنا نيست و شايد در حد بالاترى مردم و هواداران نسبت به غير اخلاقى ها واكنش نشان دهند.

قسمت ديخر تحقيق نخرش هوادارانى كه در معرض اطلاعات منفى غيراخلاقى و بى كفايتى بودند را نسبت به بازيكنان و تيم يرسيوليس با توجه به ميزان هويت آنها مورد مقايسه قرار مىداد. نتايج بيانكر اين بود كه هواداران با هويت بالا و بايين در نخرش نسبت به بازيكنان و تيم برسبوليس تفاوت معنادارى دارند، بخونهاى كه مىتوان نتيجه گرفت اطلاعات منفى غيراخلاقى و بى كفايتى در نخرش هواداران با هويت بالا تاثير بسيار كمترى نسبت به هواداران با هويت پاييين داشته است. نتيجه اين دو يافته با نتيجه تحقيق زو و ويتلا (T/ (Y) كه اذعان داشتند سطح هويت هواداران نسبت به بازيكنان و تيمهاى ورزشى در واكنش آنها به اطلاعات منفى و رسوايىهاى بازيكن و تيم متفاوت است، بخونه اى كه در مواجهه با اين اطلاعات منفى، نخرش و رفتارهاى متفاوتى از خود نشان مىدهند، هم راستا است. وقتى هو اداران با تيمى هويت بالايى داشته باشند احساس دلبستكى نيز در آنها افزايش مى يابد بخونهاى كه تيم ورزشى به بخشى جدايى نايذير از هويت شخص تبديل مى شود، به همين دليل منطقيست كه هواداران با هويت بالا، تعصب بالاترى به بازيكنان و تيم محبوب خود داشته


بزرگ براى تيم به حساب آيند. حفظ و نخهدارى اين هواداران براى هر باشخاهى از اهميت زيادى برخوردار است. بنابر اين، باشگاهها مى بايست اين نوع سرمايه را در نظر داشته باشند و در كنترل اخبار منتشر شده از باشگاه توجه كنند. از آنجا كه يافتها نشان داد هواداران با هويت يايين زودتر نخرششان نسبت به بازيكنان و تيم تغيير مىكند، روابط عمومى باشكاه مىبايست در انتشار اخبار خود توجه كافى را داشته باشد. جلو گيرى از انتشار اخبار كذب و منفى از سايتها و ديخر منابع خبرى از مهمترين وظايف روابط عمومى باشگاه است، به اين دليل كه بسيارى از هواداران با هويت يايين اخبار باشخاه را به دقت و از سايت خود باشگاه بيخيرى نمى كنند و ممكن است اين اخبار كذب و منفى از منابع خبرى، در نخرش آنها تاثير كذار باشد كه مىتواند در نهايت به از دست دادن اين هواداران منجر شود.

يافته ديكر تحقيق اخبار منفى مرتبط و غيرمرتبط با ورزش را در نكرش نسبت به بازيكنان و تيم برسبوليس بررسى كرد. قسمتى از اين يافته اخبار منفى غيراخلاقى مرتبط و غيرمرتبط با ورزش را در نخرش هواداران نسبت به بازيكنان و تيم يرسبوليس بررسى مى كرد، اخبار منفى مرتبط با ورزش در رابطه با دويينگ بازيكنان، و اخبار منفى غيرمرتبط با ورزش در رابطه با حضور در بارتى مختلط و استفاده از مشروبات الكلى و رانندگى در حالت مستى بود كه نتايج اين دو فرضيه عدم

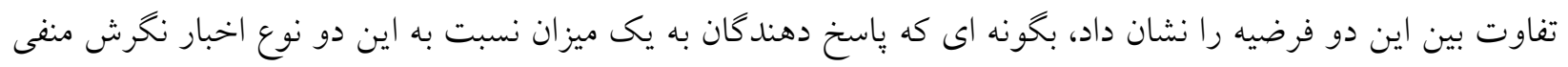




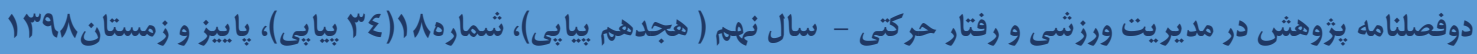

به بازيكنان و تيم برسبوليس بيدا كردند. بر اساس مبانى نظرى تحقيق و نظريه اسناد، بيش بينى مىشد هواداران نسبت به اخبار منفى غيرمرتبط با ورزش نسبت به اخبار منفى مرتبط با ورزش نخرش منفىترى داشته باشند، ولى بر اساس نتايج اين دو فرضيه تفاوت بين اين دو معنادار نبود. علت اين عدم تفاوت مىتواند به خاطر جهره منفىاى باشد كه دويينگ در كشور ما و همينطور در بسيارى از كشورهاى ديخر دارد. نتيجه اين دو يافته با نتيجه تحقيات ام (r|r.T) و بارباروسا و همكاران(T) (Y) كه نشان دادند مصرف كنند كانى كه اطلاعات منفى در رابطه با بازيكن مشهور را به عنوان يك مورد موقعيتى درى كردند، نخرش منفىترى به برند و قصد خريد نسبت به كسانى كه اين مورد را به عنوان غيرموقعيتى درى كردند، نشان دادند، ناهمسو بود. علت جنين ناهمسويى را مى توان جنين عنوان كرد كه هو اداران ممكن است خود بازيكنان

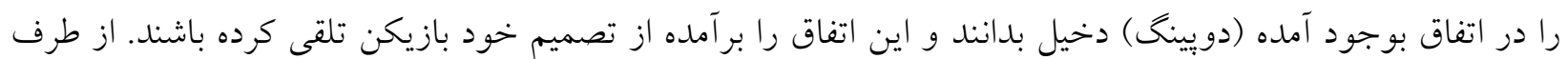
ديخر همانطور كه عنوان شد جهرهُ منفى دويينگ در سطح جامعه است كه مىتواند در نخرش هواداران به همان اندازه اخبار منفى غير اخلاقى غيرمرتبط با ورزش (حضور در يارتى مختلط و استفاده از مشروبات الكلى) تاثير گذار باشد. يافته آخر تحقيق حاضر تاثير اطلاعات منفى بى كفايتى مرتبط با ورزش و غيرمرتبط با ورزش را بر نخرش هواداران نسبت به بازيكنان و تيم برسبوليس بررسى مى كرد. همانطور كه نتايج نشان داد ميزان تاثير اخبار منفى بى كفايتى مرتبط با ورزش و غير مرتبط با ورزش بر نخرش هواداران نسبت به بازيكنان و همجنين تيم برسبوليس تفاوت معنادارى دارد. بخونه اى

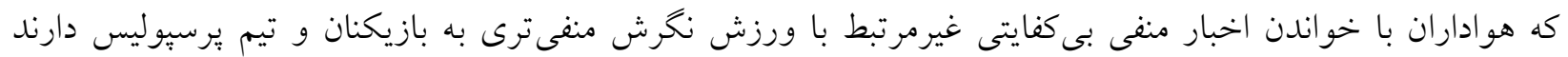
نسبت به زمانيكه اخبار منفى بى كفايتى مرتبط با ورزش را خواندند. بطور منطقى وقتى هو اداران با اخبار منفى غيرمرتبط

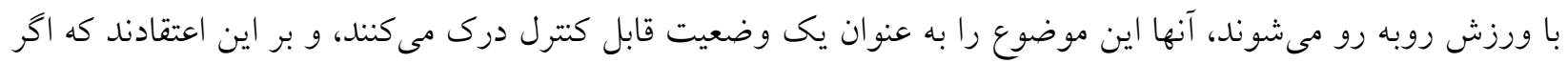
ورزشكار مواظب بود، ممكن بود جنين اتفاق منفى رخ ندهد، ولى در رابطه با اخبار منفى مرتبط با ورزش آنها جنين برداشت مى كنند كه جنين اتفاقى در جريان بازى و مسابقه بوده و از دسترس بازيكن خارج بوده است، بخصوص زمانيكه اين اخبار منفى در رابطه با كفايت و عملكرد بازيكن باشد و مسائل غيراخلاقى و فساد در ميان نباشد. نتيجه اين دو يافته با ادعاى هيدر (1901) كه اذعان مى كند عوامل داخلى، رفتارهاى عمدى را شامل مىشوند، در حاليكه عوامل خارجى

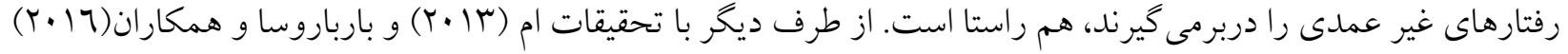
كه عوامل موقعيتى را در نخرش كاملا دخيل مى دانستند، نيز هم راستا بود.

\section{محدوديت هاى تحقيق}

در هر تحقيقى محقق با يك سرى محدوديت هايى مواجه است. تحقيق حاضر نيز از اين قضيه مستثنا نيست و محققان با يكى سرى محدوديت هايى مواجه بودند. از جمله اينكه به دليل ماهيت نيمه تجربى تحقيق حاضر و اينكه نمونه هاى تحقيق مىبايست جند سرى يرسشنامه يُ مىكردند، تعدادى از نمونهها ريزش داشت و تمام نمونهاى تحقيق تا يايان همراهى نكردند. از ديخر محدوديتها، جامعه تحقيق مىباشد كه همه سنين را مورد بررسى قرار نمىدهد و تمركز بر دانشجويان است كه با توجه به سن آنها احتمالا از هواداران تاثير گذار هر تيمى به شمار مىروند. با اين حال عدم بررسى هواداران 


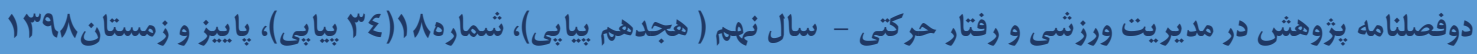

بزركسال و سالمند از محدوديت ديخر تحقيق بود. از ديخر محدوديت هاى تحقيق حاضر عدم بررسى هواداران زن بود كه به دليل حجم زياد تحقيق كه متغيرهاى متعددى را مورد بررسى قرار مىداد و براى جلو گيرى از سردرگمى خواننده فقط هواداران مرد را مورد بررسى قرار داد.

كاربردهاى عملى

نتايج به دست آمده از تحقيق حاضر مهى تواند براى باشخاههاى ورزشى و به خصوص باشخاههاى يرطرفدار سودمند باشد. با توجه به نتايج تحقيق كه به اهميت اخبار منفى غيراخلاقى اشاره كرد و تاثير آن در ايجاد نكرش منفى نسبت به بازيكنان و تيم يرسيوليس اثبات شد، بيشنهاد مى شود باشخاههاى يرطرفدار همجيون باشخاه برسيوليس نسبت به مسائل اخلاقى

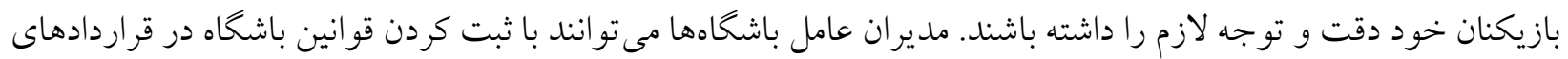
بازيكنان آنها را ملزم به رعايت قوانين و جارجوب هاى اخلاقى كنند. جراكه ورزش حرفه اى نيازمند يك سرى اصول و قوانينى است كه بازيكنان بايد آنها را رعايت كنند. كسر درصدى از قرارداد در صورت بوجود آمدن مسائل غير اخلاقى از طرف بازيكنان مىتو اند در جلو گيرى از بوجود آمدن اين نوع مسائل موثر باشد. از نتايج ديخر تحقيق تفاوت در شكل كيرى بـ

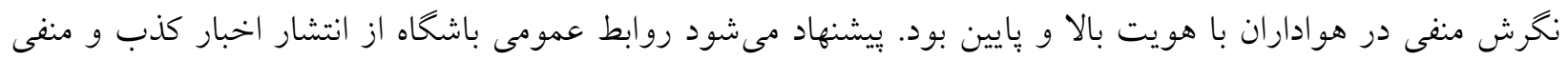
توسط ديكر خبر گزارىها جلو گيرى كند، همجنين برخورد قاطع با خبرنگارهايى كه در يى ايجاد حاشيه براى بازيكنان

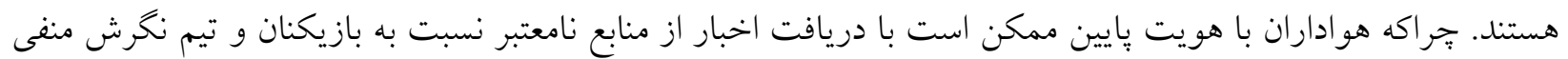
بيدا كنند كه مى تواند منجر به از دست دادن جنين هوادارانى شود و در نتيجه به عدم حضور اين هواداران در ورزشكاه و كاهش درآمد مالى منجر شود.

\section{تحقيقات براى آينده}

با وجود نتايج حاصل از اين تحقيق، جاى خالى تحقيقات بيشتر در اين زمينه به جشم مى خورد. بيشنهاد مىشود اخبار

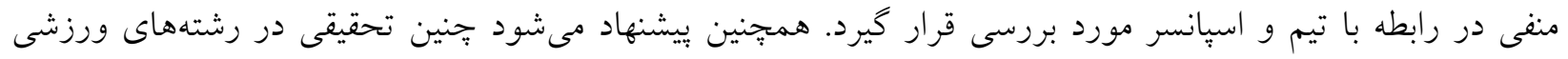
يرطرفدار ديكر در كشور ما مانند واليبال و كشتى نيز انجام شود. همجنين بيشنهاد مى شود يكى مطالعه بين فرهنكى در جند كشور انجام شود و مطالعات بدست آمده از جند كثور با هم مقايسه شود. بيشنهاد مى شود علاوه بر متغيرهاى بررسى شده در اين تحقيق متغيرهاى ديخرى مانند ميزان دركيرى هواداران با ورزش نيز مورد بررسى قرار گيرد. 
1. Monga, A. John, D.(2008). When does negative brand publicity hurt? The moderating influence of analytic versus holistic thinking. Journal of Consumer Psychology 18 (2008) 320-332.

2. Poniewozik, J. (2014). Is this thing on? Why social media keeps taking down media celebs. Retrieved July 4.

3. Somaiya, R. (2015). Brian williams scandal shows power of social media. Retrieved July 4.

4. Carlson, B.D., \& Donavan, D.T. (2013). Human brands in sport: Athlete brand personality and identification. Journal of Sport Management, 27, 193-206.

5. Rafiee, V. Shen, K. (2016). The impact of corporate response strategies to negative online word of mouth on complainers' brand attitude. PACIS 2016 Proceedings. 292.

6. Fishbein, M., \& Ajzen, I. (1970). Belief, attitude, intention, and behavior: An introduction to theory and research

7. Eastin, M. Ciccirillo, V. Dudo, A. Sparvero, E. Wilcox, G.(2016). The Influence of Team and Athlete Identification on Sport Consumer Behavior and Fan Response to Negative Information. Dissertation Presented to the Faculty of the Graduate School of The University of Texas at Austin.

8. Klein, J.G. (1996). Negativity in impressions of presidential candidates revisited: The 1992 election. Personality and Social Psychology Bulletin, 22(3), 288-295.

9. Herr, P.M., Kardes, F.R., \& Kim, J. (1991). Effects of word-of-mouth and product-attribute information on persuasion: An accessibility-diagnosticity perspective. Journal of Consumer Research, 17(4), 454-462.

10. Klein, J.G., \& Ahluwalia, R. (2005). Negativity in the evaluation of political candidates. Journal of Marketing, 69(1), 131-142.

11. Ahluwalia, R., Unnava, H.R., \& Burnkrant, R.E. (2001). The moderating role of commitment on the spillover effect of marketing communications. Journal of Marketing Research, 38(4), 458-471.

12. Simonin, B.L., \& Ruth, J.A. (1998). Is a company known by the company it keeps? Assessing the spillover effects of brand alliances on consumer brand attitudes. Journal of Marketing Research, 35(1), 30-42.

13. Um NH, Kim S. 2016. Determinants for effects of celebrity negative information: when to terminate a relationship with a celebrity endorser in trouble? Psychology \& Marketing 33(10): 864-874.

14. Louie, T.A., \& Obermiller, C. (2002). Consumer response to a firm's endorser (dis)association decisions. Journal of Advertising, 31(4), 41-52.

15. Yoon, S. Shin, S. (2017). The role of negative publicity in consumer evaluations of sports stars and their sponsors. Journal of Consumer Behaviour, J. Consumer Behav. (2017). DOI: $10.1002 / \mathrm{cb} .1636$.

16. Burton JL, Hill DJ, Bakir A. 2015. Influencing light versus heavy engagers of harmful behavior to curb their habits through positive and negative ad imagery. Journal of Consumer Behaviour 14(4): 237-247.

17. Wojciszke B, Bazinska R, Jaworski M. 1998. On the dominance of moral categories in impression formation. Personality and Social Psychology Bulletin 24(12): 1251-1263.

18. Wojciszke B, Brycz H, Borkenau P. 1993. Effects of information content and evaluative extremity on positivity and negativity biases. Journal of Personality and Social Psychology 64(3):327-335. 
19. Wojciszke B. 2005. Morality and competence in person-and selfperception. European Review of Social Psychology 16(1): 155-188.

20. Abrams, D., \& Hogg, M. A. (1988). Social identifications: A social psychology of intergroup relations and group processes: Routledge.

21. Wakefield, K. L.(1998). Affective intensity and sponsor identification. Journal of advertising, 39(3), $111-99$

22. Ahn T, Suh Y, Lee J, Pedersen PM. 2012. Sport fans and their teams' redesigned logos: an examination of the moderating effect of team identification on attitude and purchase intention of team-logoed merchandise. Journal of Sport Management 27 (1): 11-23.

23. Lock D, Funk DC, Doyle JP, McDonald H. 2014. Examining the longitudinal structure, stability, and dimensional interrelationships of team identification. Journal of Sport Management 28 (2): 119-138.

24. Zhou L, Whitla P. 2013. How negative celebrity publicity influences consumer attitudes: the mediating role of moral reputation. Journal of Business Research 66(8): 1013-1020.

25. Barbarossa C, De Pelsmacker P, Moons I, Marcati A. 2016. The influence of country-oforigin stereotypes on consumer responses to food safety scandals: the case of the horsemeat adulteration. Food Quality and Preference 53: 71-83.

26. Kelly EL. 1967. Assessment of Human Characteristics. Brooks/Cole Publishing Company: Belmont, CA.

27. Heider F. 1958. The Psychology of Interpersonal Relations. Wiley: New York, NY.

28. Weiner B. 1979. A theory of motivation for some classroom experiences. Journal of Educational Psychology 71(1): 3-25.

29. Coombs WT. 2007. Attribution theory as a guide for post-crisis communication research. Public Relations Review 33(2): 135-139.

30. Shaw ME, Sulzer JL. 1964. An empirical test of Heider's levels in attribution of responsibility. The Journal of Abnormal and Social Psychology 69(1): 39-46.

31. Coombs WT, Holladay SJ. 2002. Helping crisis managers protect reputational assets initial tests of the situational crisis communication theory. Management Communication Quarterly 16(2):165-186.

32. Um NH. 2013. Celebrity scandal fallout: how attribution style can protect the sponsor. Psychology and Marketing 30(6): 529-541.

$$
\text { سب. سكاران، اميد(• وجr). روش هاى تحقيق در مديريت. موسسه مديريت و برنامه ريزى آموزشى و يزوهشى. تهران، ايران. }
$$

